\title{
FULBRIGHT
}

Represent American Scholarship Abroad

The 2014-15

Fulbright U.S.

Scholar

Program is now

$$
\text { open. }
$$

More than 800 grants available for teaching, research or both in $125+$ countries

All program information is available at www.iie.org/cies 
Copyright (C) 2013 Slavic Review ISSN 0037-6779 by the Association for Slavic, East European, and Eurasian Studies, Inc. Permission to reprint must generally be obtained from Slavic Review. Copying is permitted in accordance with the fair use guidelines of the US Copyright act of 1976. The association permits the following additional educational uses without permission or payment of fees: academic libraries may place materials from Slavic Review on reserve (in multiple photocopied or electronically retrievable form) for students enrolled in specific courses; teachers may reproduce or have reproduced multiple copies (in photocopied or electronic form) for students in their courses. Those wishing to reproduce material from Slavic Review for any other purpose (general distribution, advertising or promotion, creating new collective works, resale, etc.) must obtain permission from Slavic Review.

Slavic Review is indexed in ABSEES (American Bibliography of Slavic and East European Studies). Articles appearing in this journal are abstracted or indexed in Historical Abstracts, America: History and Life, ABC Pol Sci: A Bibliography of Contents, Academic Index, Arts and Humanities Citation Index, Linguistic Bibliography, Book Review Index, Historical Abstracts, Humanities Index, MLA, PAIS, RILM, Social Science Index, Social Science Citation Index, Current Contents/Social and Behavioral Sciences, International Bibliography of theSocial Sciences, and Cross Ref.

All issues of Slavic Review are available online through JSTOR for institutional subscribers and ASEEES members. For more information, please visit about.jstor.org/csp or contact participation@jstor.org.

Slavic Review is published at the University of Illinois, Urbana-Champaign, with support from the College of Liberal Arts and Sciences, the Russian, East European, and Eurasian Center, the Department of History, and the Humanities Council.

Articles, books for review, and correspondence concerning editorial matters, advertising, or permissions should be sent to Slavic Review, University of Illinois, 1207 W. Oregon St., Urbana, IL 61801-3716. Telephone: (217) 333-3621; e-mail: slavrev@illinois.edu.; Web site: http://www. slavicreview.illinois.edu.

Before submitting manuscripts to Slavic Review, please consult the Information tab on our Web site for details on criteria, acceptable length, and preparation of the manuscript.

Slavic Review does not ordinarily accept unsolicited book reviews. Please consult us if you would like to propose a book for review or a review essay.

Slavic Review publishes signed letters to the editor by individuals with educational or research merit.

For more detailed policy statements on manuscript submissions, book reviews, and letters to the editor, see our Web site. 


\section{THE NOBILITY OF POLAND}

By Xavier Jon Puslowski

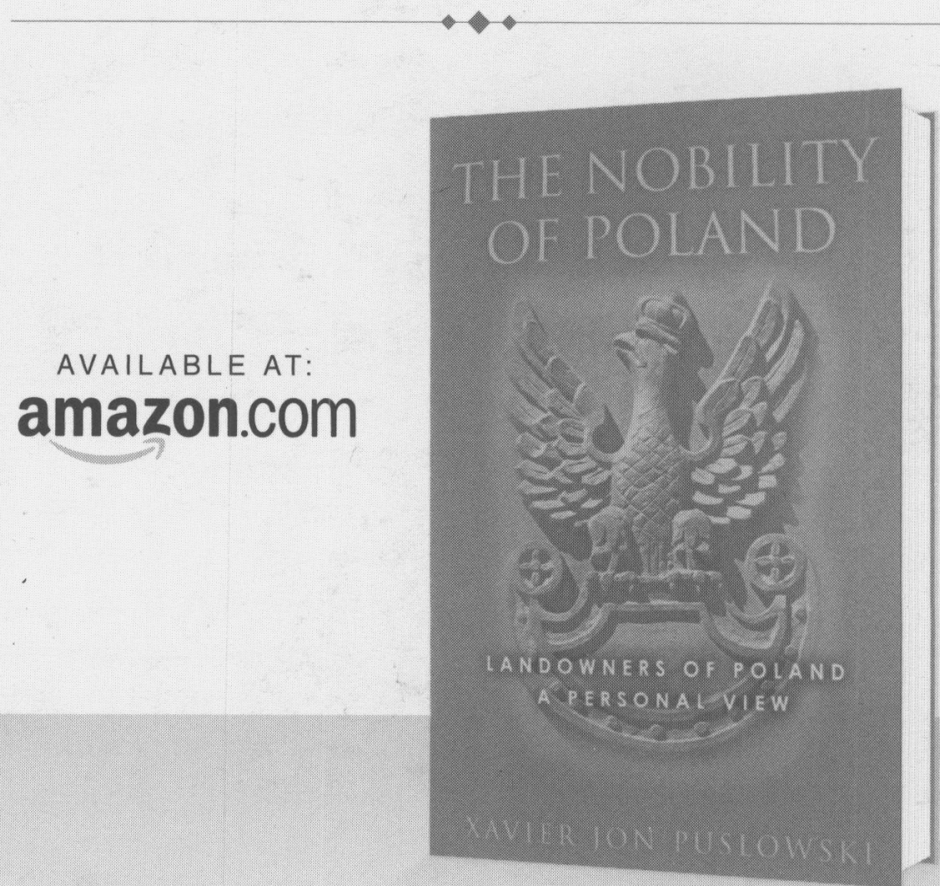

Action-filled as any thriller, this historic panorama brings to life a little known and long defunct society: the Polish nobility, from their origins to their political demise during World War II.

Beginning with a mysterious murder, still unsolved, whose aftereffects shook Polish society to its core, the narrative unfolds until it reaches the 1940s. Chapters range from the nobility's day-to-day lives to such striking landmarks as the seventeenth century wars with the Ottoman Empire, the saga of Europe under the Napoleonic tricolor, and the centrality of Poland to the Eastern Front throughout the course of World War I. 